\title{
Combatment of Aquatic Pollution through Biofilm Technique: A Review
}

\author{
Rashmi Prabha Mishra1, Chandra Kanta Mishra², \\ Navin Kumar ${ }^{3}$ and Sudhir Kumar Das ${ }^{4}$ \\ '(Fishery Sc.), Krishi Vigyan Kendra, Angul, Odisha, India \\ ${ }^{2}$ Regional Research Centre, CIFA, Anand, Gujarat, India \\ ${ }^{3}$ Agriculture Coordinator, District agriculture office, Samastipur, India \\ ${ }^{4}$ Department of Fisheries Resource Management, WBUAFS, Kolkata, India
}

*Corresponding author

\begin{abstract}
A B S T R A C T
Aquatic pollution occurs due to the discharge of harmful substances, chemicals or microorganisms into water bodies i.e. a stream, river, lake, ocean, aquifer, or other body of water resulting in contamination \& degradation of water quality and rendering it unsuitable

Keywords

Combatment, Aquatic pollution, Biofilm technique

Article Info

Accepted:

12 March 2020

Available Online:

10 April 2020 for human use or the environment. Many advanced water treatment techniques are followed before discharging this polluted water into the surrounding environment. However some limitations is there. In this context, Biofilms have become the important part of biological treatment of municipal waste water. Biofilm reactors are units where biofilm rich sludge are used in treatment of wastewater through many biological processes. Among all treatment methods Biofilm based bioreactors are considered as best available technologies for waste water treatment. Biofilms are complex structured porous and most tolerant communities of the aquatic ecosystem that includes environmentally efficient strains of algae, fungi, bacteria, actinomycetes and viruses. These microbial isolates have been extensively studied for assimilation, bio-sorption and biodegradation of almost all sorts of organic and inorganic pollutants in aquatic ecosystems. Further research is needed to bio-stimulate the promising strains of biofilms for pollution treatment. Considering the increased pollution stress, its negative impact on aquatic life and potential of aquatic biofilms to be used as indicators of pollution for controlling this pollution is reviewed in this study.
\end{abstract}

\section{Introduction}

Aquatic pollution causes due to the discharge of harmful substances, chemicals or microorganisms into water bodies i.e. a stream, river, lake, ocean, aquifer, or other body of water resulting in contamination and degradation of water quality and rendering it unsuitable for human use or the environment. It can be classified as surface water or groundwater pollution.

Marine pollution and nutrient pollution are subsets of Aquatic pollution. Sources of this 
are either point sources or non-point sources. Point sources have one identifiable cause of the pollution, such as a storm drain or a wastewater treatment plant. Non-point sources are more diffuse, such as agricultural runoff (Moss et al., 2008). Worldwide causes of death and disease is due to this aquatic pollution, e.g. due to water-borne diseases (west et al., and Pink et al., 2006). It is leading to the deaths of 1.8 million people in 2015 (Kelland et al., 2017). India and China are two countries with high levels of water pollution.

An estimated 580 people in India die of water pollution related illness (including waterborne diseases) every day (CHNRI, 2010). About 90 percent of the water in the cities of China is polluted (Chinadaily. Com. 2005). As of 2007, half a billion Chinese had no access to safe drinking water (Kahan et al., 2007). This pollution is measured by analysing water samples through Physical, chemical and biological methods. In this context Biofilms in aquatic ecosystems colonize various surfaces (sand, rocks, leaves) and play a major role in the biological control of pollution. Aquatic biofilms supply energy and organic matter to the food chain, they are important in recycling organic matter and contribute to water quality.

A biofilm is defined as "an assemblage of microbial cells that is irreversibly associated with a surface and enclosed in a matrix of primarily polysaccharide material. (Kelley and Firestein's Textbook of Rheumatology., Tenth Edition, 2017). For assessment of pollution stress and investigation in a faster rate at community level with numerous endpoints living communities are used in monitoring studies (Gold et al., 2002; Mages et al., 2004; Kropfl et al., 2006; Xuemei et al., 2010; DeForest et al., 2016). Stress monitoring and restoration of aquatic ecosystems required the skill to label ecological change precisely using measurable indicators (Ryder and Miller 2005; Lear et al., 2009). In streams which are passing through agricultural areas, mixtures of chemicals derived from agricultural activity may directly or indirectly affect community structure and function of Biofilm (Boivin et al., 2006). Biofilms inhabit the base of the trophic level of the food chain of streams and help in fueling energy to higher trophic levels driving carbon and nutrient cycles (Battin et al., 2008). Microbial biofilms actively take part in the degradation of plant and animal remains, cycling of nutrients and elimination of suspended sediments in the aquatic environment.

\section{Need of biofilm technology in aquatic pollution study}

Biofilms having many of the important characteristics needed for community level monitoring studies: (1) they are extensively disseminated; (2) they are sessile, thus can imitate the actual circumstances of habitat; (3) they react more quickly to environmental fluctuations because of their short life cycle than higher level organisms; (4) these communities are composed of diverse taxonomic populations with varying environmental tolerance; (5) biofilm samples can be easily collected (Kropfl et al., 2006; Nocker et al., 2007; Porsbring et al., 2007; Xuemei et al., 2010). Biofilms are good bioindicators and biomarkers, offering a suitable tool to screen metal pollution in water bodies. Benthic biofilms possess multiple functions in the development of stream and riverine ecosystems and production are frequently restricted by availability of dissolved inorganic nutrients i.e. $\mathrm{N}$ or $\mathrm{P}$ (Reisinger $e t$ al., 2016). Autotrophic and heterotrophic organisms' living inside a given biofilm are often restricted by various nutrients despite experiencing analogous physical and chemical circumstances provided by 
superimposing river water (Johnson et al., 2009; Hoellein et al., 2010; Reisinger et al., 2016). Biofilm helps in the buildup of metal pollutants that are sensitive to the defensive effect of major cations and protons (as for many aquatic living organisms) (Leguay et al., 2016). The dominance of green algae in the biofilms is indicated by the the presence of quantity of pigments i.e. chlorophyll. Pigment composition changes after brief exposure to pollution load and can be used as a biochemical marker of toxic effects (Sabater et al., 2007; Xuemei et al., 2010). Stream ecosystems primarily derive nutrients and organic carbon from terrestrial ecosystems and this process is dependent on the land use of the adjacent landscape. (Qu et al., 2017; Teittinen et al., 2015; Smucker et al., 2013; Ren et al., 2013) and an influence of land cover conditions on biofilm stoichiometry (O'Brien and Wehr 2010; Qu et al., 2017). Considering the increased pollution stress, its negative impact on aquatic life and potential of aquatic biofilms to be used as indicators of pollution for controlling this pollution is reviewed in this study.

\section{Concept of biofilm}

Biofilms are complex communities composed primarily of autotrophic (algae) and heterotrophic microbes (bacteria, fungi, protozoa) which accumulate at surfaces of man-made or natural substrata and are characteristically enclosed by their secretory products such as the milieu of extracellular polymeric substances (EPS) (Sekar et al., 2002; Kropfl et al., 2006; Denkhaus et al., 2007). EPS regulate the structural and functional integrity of microbial biofilms and contribute significantly to the organization of the biofilm community (Branda et al., 2005). EPS components presented in Table 1 are typically aggregates of extracellular polysaccharides, proteins and lipids and DNA (Daniel et al., 2010; Hall-Stoodley et al., 2004; Aggarwal et al., 2016).

\section{Process of biofilm technology}

Biofilm is defined as communities or clusters of microorganisms that attached to a surface (O Toole et al., 2000 and Singh et al., 2006). Formation of biofilm could be possible by a single or multispecies of microorganisms that have the potential to form at biotic and abiotic surfaces (O. Toole et al., 2000). As a general, there are few steps that important for development of biofilm, which starting with the initial attachment and establishment to the surface, followed by maturation, and finally, the detachment of cells from surface ( $\mathrm{O}$ Toole et al., 2000; Singh et al., 2006; Watnick et al., 2000).

\section{Biofilm diversity and distribution patterns}

Biofilms are the assemblage of group of microorganisms, such as bacteria, algae, fungi, protozoa and viruses and all of them form important part of the biofilm community and add to the diversity of aquatic ecosystems (Stoodley et al., 2002; Battin et al., 2007; Jackson and Jackson 2008). The diversity of biofilms often depends on the form of substrate and aquatic medium in which they are formed. Varity of microorganisms used as Biofilm are given below.

\section{Waste water treatment through biofilm technique}

Biofilms have become the important part of biological treatment of municipal waste water and there are various technologies used for treatment of waste water. A few of them are presented below. Biofilm reactors are units where biofilm rich sludge are used in treatment of wastewater through many biological processes. Biofilm reactors are differentiated according to - (1) The number of phases involved (2) As per biofilm attached to a fixed or moving carrier within the reactor and (3) How electron donors or accepters are used. 


\section{Advantages of biofilm technique}

\section{Environmental cleanup}

Biofilms play an important role in industrial and ecological significance and decontamination of polluted water. Biofilm have the ability to degrade the industrial chemical pollutants by using them as a carbon source (Sgountzos et al., 2006). Biofilms helps in bioremediation of heavy metals and degradation of some harmful chemicals in the environment and can also be used as bioindicators of pollution. There are different groups of microbes in aquatic bodies that have been tested for decontamination of waste water (Srivastava et al., 2017).

\section{Water decontamination}

This can be possible by the process of removal of contaminants from polluted water by the use of living organisms such as microorganisms from biofilms. It includes the basic mechanism of assimilation, adsorption and biodegradation.

\section{Assimilation of nutrients}

Every organism requires some sort of nutrients such as nitrogen and phosphorous for better growth and survival. These nutrients are compulsory for microbial growth. Microbes use inorganic forms of nitrogen as a sole source of nitrogen for growth. Nitrate and phosphate assimilation occurs during the agitation period of the anaerobic-aerobic activated sludge process in the first reactor and during aeration and denitrification in the second reactor (Yariv 2001; Villaverde 2004; Wu et al., 2012).

\section{Adsorption of contaminants}

Adsorption of microorganisms and their aggregates is generally called as bio-sorption. This process is needed for removal of metal from the water. Bio-sorption in biofilms is shown by bacteria (e.g. Pseudomonas aeruginosa), fungi (Aspergillusniger) and algae (Chaetomorphalinum) (Joo et al., 2010; Fu and Wang 2011). The mechanism of biosorption of metals and other dies involves the use of special features of these microorganisms such as adhesion and flocculation properties. Bio-sorption does not produce toxic materials and biofilms maintain their heterogeneity by extracellular polymeric substance (Wu et al., 2012). The structure of biofilms is important in metal adsorption and porous structure of microbial aggregates in biofilms enables active bio-sorption ( $\mathrm{Wu}$ et al., 2010) (Fig. 1 and 2, Table 2 and 3).

Table.1 Composition of a Biofilm

\begin{tabular}{|c|c|c|}
\hline S. No. & Component & Percentage of Matrix \\
\hline $\mathbf{1}$ & Water & $97 \%$ \\
\hline $\mathbf{2}$ & Microbial cells & $2-5 \%$ \\
\hline $\mathbf{3}$ & Polysaccharides & $1-2 \%$ \\
\hline $\mathbf{4}$ & Proteins & $<1-2 \%$ (includes enzymes) \\
\hline $\mathbf{5}$ & DNA and RNA & $<1-2 \%$ \\
\hline $\mathbf{6}$ & Ions Bound and free & \\
\hline
\end{tabular}

Source: http://microbewiki.kenyon.edu/index.php/Stream_biofilm 
Table.2 The list of microorganisms as Biofilm for the removal of different kinds of pollutants

\begin{tabular}{|c|c|c|}
\hline Microbial isolates from biofilms & Role in environmental cleanup & References \\
\hline $\begin{array}{l}\text { Pseudomonas, Chryseomonas, } \\
\text { Sphingomonas and Burkholderiae } \\
\text { species }\end{array}$ & $\begin{array}{l}\text { Biodegradation of phenol and pyridine and the } \\
\text { highest biodegradation capacity ( } 1700 \mathrm{mg} / \mathrm{L} \text { and } \\
3000 \mathrm{mg} / \mathrm{L} \text { of phenol and pyridine respectively) is } \\
\text { shown by Pseudomonas } M T 1 \text { isolate. }\end{array}$ & $\begin{array}{l}\text { Rakaiby et al., } \\
\text { (2012) }\end{array}$ \\
\hline $\begin{array}{l}\text { Pseudomonas stutzeri, } \\
\text { Aeromonascaviae, } \\
\text { Sphingobacterium thalpophilum, } \\
\text { Fusarium udum and Hodotorula } \\
\text { mucilaginosa }\end{array}$ & Reduction of BOD and COD values of wastewater. & $\begin{array}{l}\text { Bestawy et al., (2014) and Rozitis } \\
\text { and Strade (2014) }\end{array}$ \\
\hline $\begin{array}{l}\text { Bacillus amyloliquefaciens (S1), E. } \\
\text { coli (Rz6) and their mixed culture. } \\
\text { Pseudomonas otitidis }\end{array}$ & $\begin{array}{l}\text { Removal of Total Suspended Solids, Fat, Oil, } \\
\text { Grease and Total Coliform from waste water. } \\
\text { Pseudomonas otitidis has been evaluated for crude } \\
\text { oil degradation }\end{array}$ & $\begin{array}{l}\text { Bestawy et al., (2014) and } \\
\text { Dasgupta et al., (2013) }\end{array}$ \\
\hline $\begin{array}{l}\text { Pseudomonas stutzeri B. denitrificans } \\
\text { B79 and A. hydrophila L6, } \\
\text { Rheinheimera pacifica, Thauera sp. }\end{array}$ & $\begin{array}{l}\text { Biological denitrification of wastewater and the } \\
\text { river water }\end{array}$ & $\begin{array}{l}\text { SriuNaik and PydiSetty (2011), } \\
\text { Andersson (2009) and Jiang et al., } \\
\text { (2008) }\end{array}$ \\
\hline $\begin{array}{l}\text { Comamonas, Thauera, Paracoccus, } \\
\text { Paracoccus sp. and Azoarcus }\end{array}$ & $\begin{array}{l}\text { Act as heterotrophic nitrifiers in aquatic systems } \\
\text { and at a laboratory scale for nitrification }\end{array}$ & $\begin{array}{l}\text { Wang et al., (2014), Cydzik- } \\
\text { Kwiatkowska (2015) and Ma et al., } \\
\text { (2015) }\end{array}$ \\
\hline $\begin{array}{l}\text { Nitrosomonas sp. and Candidatus } \\
\text { kuenenia }\end{array}$ & $\begin{array}{l}\text { Removal of Ammonium from highly concentrated } \\
\text { streams }\end{array}$ & Park et al., (2014) \\
\hline $\begin{array}{l}\text { Phosphorous Accumulating } \\
\text { Organisms (PAO) such as } \\
\text { Accumulibacter sp., Tetrasphaera sp. } \\
\text { and Dechloromonas sp. }\end{array}$ & Phosphorous removal from contaminated water & $\begin{array}{l}\text { Oehmen et al., 2007, Nielsen et } \\
\text { al.,(2010), Nguyen et al., (2011) } \\
\text { and Kong et al., (2007) }\end{array}$ \\
\hline $\begin{array}{l}\text { Marine strain P. mendocina } \mathrm{NR} 802 \text {, } \\
\text { Pseudomonas paucimobilis, } \\
\text { Sphingomonasbisphenolicum and } \\
\text { Sphingomonas } \mathrm{sp} \text {. AO1 }\end{array}$ & $\begin{array}{l}\text { Biodegradation of PAHs from polluted water and } \\
\text { other micro-pollutants such as PAH and Bisphenol } \\
\text { A. }\end{array}$ & $\begin{array}{l}\text { Mangwani et al., (2013) and } \\
\text { Kwiatkowska and Zielinska } 2016\end{array}$ \\
\hline $\begin{array}{l}\text { Pseudomonas putida, Geobacter } \\
\text { metallireducens }\end{array}$ & $\begin{array}{l}\text { Bioremediation of heavy metals from metal } \\
\text { polluted water. }\end{array}$ & Singh and Cameotra (2004) \\
\hline $\begin{array}{l}\text { Acinetobacter sp., Graphium sp., } \\
\text { Fusarium sp., Candida tropicalis }\end{array}$ & $\begin{array}{l}\text { Decontamination of phenol and m-cresol } \\
\text { containing wastewater }\end{array}$ & $\begin{array}{l}\text { Wang et al., (2007) and Santos and } \\
\text { Linardi (2004) }\end{array}$ \\
\hline $\begin{array}{l}\text { P. aeruginosa ASU 6a (Gram- } \\
\text { negative) and Bacillus cereus AUMC } \\
\text { B52 (Gram-positive) }\end{array}$ & $\begin{array}{l}\text { Low cost and effective bio-sorbants for removal of } \\
\mathrm{Zn} \text { (II) from wastewater }\end{array}$ & Joo et al., (2010) \\
\hline $\begin{array}{l}\text { Acinetobacter calcoaceticus, } \\
\text { Erwiniaherbicola, P. aeruginosa and } \\
\text { Pseudomonas maltophilia }\end{array}$ & Affinity for bio-sorption of Gold (Au) & Tsuruta (2004) \\
\hline Escherichia coli & $\begin{array}{l}\text { Elimination of numerous heavy metals, such as } \\
\text { lead }(\mathrm{Pb}) \text {, copper }(\mathrm{Cu}) \text {, cadmium }(\mathrm{Cd}) \text {, and zinc } \\
(\mathrm{Zn})\end{array}$ & Kao et al., 2006) \\
\hline $\begin{array}{l}\text { Microcystins degrading bacteria such } \\
\text { as Sphingpoyxis sp. and } \\
\text { Sphingomonas sp. }\end{array}$ & $\begin{array}{l}\text { Removal of some specific compounds such as } \\
\text { microsytin-RR, aliphatic homopolyesters and } \\
\text { aliphatic-aromatic copolyesters. }\end{array}$ & $\begin{array}{l}\text { Wu et al., (2010) and Abou-Zeid } \\
\text { et al., 2004) }\end{array}$ \\
\hline $\begin{array}{l}\text { Basidiomycetes, A. niger and } \\
\text { Trichoderma sp. }\end{array}$ & $\begin{array}{l}\text { Biosorption of dyes from contaminated water such } \\
\text { as Congo red, Orange G. etc. }\end{array}$ & $\begin{array}{l}\text { Tatarko and Bumpus (1998) and } \\
\text { Sivasamy and Sundarabal (2011) }\end{array}$ \\
\hline
\end{tabular}


Table.3 Types of biofilm reactors

\section{Types of Reactor}

Trickling filter (Three-phase system - fixed biofilm-laden carrier, bulk water, and air).

Submerged fixed bed biofilm reactor operated as up flow or down flow (Three-phase system fixed (or semi fixed) biofilm-laden carrier, bulk water and air)

Aerobic moving bed biofilm reactor or MBBR (Three-phase system - moving biofilm-laden carrier, bulk water, and air. Water flows through the Biofilm reactor)

Denitrification fluidized bed biofilm reactor or FBBR (Two-phase system - moving biofilmladen carrier and bulk water)

Denitrification filter (Two-phase system - fixed biofilm-laden carrier material and bulk water)

Membrane biofilm reactor or MBfR (Threephase membrane system)

The biofilm-based microbial fuel cell or MFC (Two-phase membrane system)

\section{Function}

Here water drips over the surface of the biofilm and air is subjected to pass upward or downward in the third phase Fig. $3 a$.

Water and gas bubbles (Aerobic and bioactive filter) flow through the biofilm reactor. Here gravel is immovable media and polystyrene beads act as semi-fixed media Fig. 3b, c.

Here water flows through the biofilm reactor and air is introduced with gas bubbles Fig. 3g. MBBRs can be used as single stage or multistage reactors. They are efficient enough to meet water quality standards for carbon oxidation, nitrification, and denitrification.

Water is allowed to flow through the biofilm reactor having electron donor and accepter Fig. 3g.

Water is allowed to flow through the electron donor and accepter Fig. 3b, c.

It is made of a microporous hollow membrane having water and biofilm on one side of the membrane and gas on the other side and gas is allowed to diffuse through the membrane to the biofilm Fig. 3h.

It contains a proton exchange membrane which splits a classified biofilm-laden anode from a classified cathode with water on both sides. The electron donor is also separated from electron acceptor by this membrane. Other methods of waste water treatment include constructed wetlands and lagoons where the application of biofilm is vital in nutrient removal along with certain macrophytes.

Source: (Lewandowski et al., 2011)

Figure.1 Stages of biofilm development (Cogen and Keener, 2004)

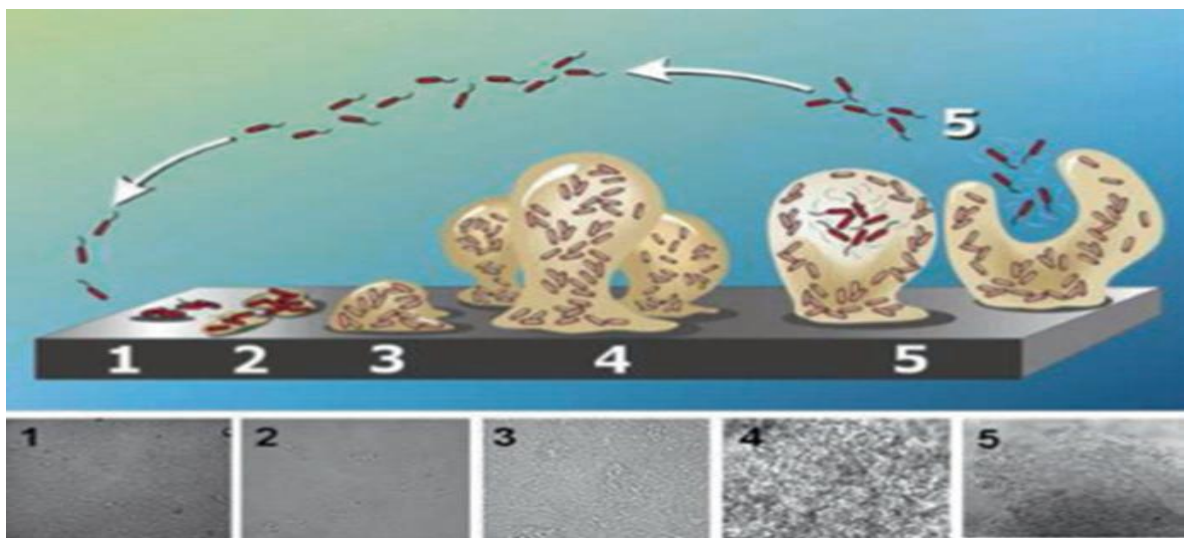


Table.4 Lists of biofilm reactors used for the wastewater treatment

\begin{tabular}{|c|c|c|c|}
\hline \multicolumn{2}{|c|}{ Description } & Type of wastewater & References \\
\hline \multicolumn{4}{|c|}{ Aerobic membrane bioreactor (MBR) } \\
\hline & $\begin{array}{l}\text { functions as dual mechanism which membrane } \\
\text { filtration occurs along with biodegradation processes } \\
\text { water and small solution molecules pass through the } \\
\text { membrane while solid materials, biomass, and } \\
\text { macromolecules are retained in the reactor }\end{array}$ & $\begin{array}{l}\text { Can treat high- } \\
\text { strength synthetic } \\
\text { wastewater }\end{array}$ & $\begin{array}{l}\text { (Dhaouadi } \\
\text { et al., 2008) }\end{array}$ \\
\hline Rotating & $\begin{array}{l}\text { biological contactor (RBC) } \\
\text { operates by attaching microorganisms to an inert } \\
\text { support matrix to form a biofilm support matrix and a } \\
\text { sequential disc configuration is placed partially or } \\
\text { totally submerged in the reactor and it will rotates } \\
\text { around a horizontal axis slowly where the wastewater } \\
\text { flows through into it }\end{array}$ & $\begin{array}{lr}\text { Can treat } & \text { high- } \\
\text { strength } & \text { synthetic } \\
\text { wastewater } & \text { with } \\
\text { chemical } & \text { oxygen } \\
\text { demand } & \text { (COD) } \\
\text { concentration } & \text { up to } \\
12000 \mathrm{mg} / \mathrm{L} & \end{array}$ & $\begin{array}{l}\text { (Von } \\
\text { sperling et } \\
\text { al., 2005) }\end{array}$ \\
\hline \multicolumn{4}{|c|}{ Anaerobic-aerobic granular biofilm bioreactor } \\
\hline & $\begin{array}{l}\text { granular biofilm bioreactor consists of an upflow } \\
\text { anaerobic sludge bed (UASB), having an aeration } \\
\text { column or sparger placed in the middle of the reactor } \\
\text { anaerobic and aerobic populations of the biofilm co- } \\
\text { exist closely in the same reactor offers a good } \\
\text { strategy to complete mineralisation of highly } \\
\text { substituted compounds }\end{array}$ & $\begin{array}{l}\text { Treat various } \\
\text { chlorinated } \\
\text { pollutants }\end{array}$ & $\begin{array}{l}\text { (Tartakovsk } \\
\mathrm{y} \text { et al., } \\
2005)\end{array}$ \\
\hline \multicolumn{4}{|c|}{ Anaerobic-aerobic fixed film bioreactor (FFB) } \\
\hline & $\begin{array}{l}\text { combination of two fixed-film bioreactor with } \\
\text { arranged media (anaerobic and aerobic) connected in } \\
\text { series with recirculation system gives advantages as } \\
\text { less sensitivity to environmental variations and } \\
\text { higher growth rate due to the used of immobilised } \\
\text { cells on the surface of the media }\end{array}$ & $\begin{array}{l}\text { Treat wastewater } \\
\text { that have high } \\
\text { content of oil and } \\
\text { grease }\end{array}$ & $\begin{array}{l}\text { (Del Pozo } \\
\text { et al., 2003) }\end{array}$ \\
\hline & $\begin{array}{l}\text { use a cylindrical fluidised bed with pulverised } \\
\text { pumice-stone as support material for microorganisms } \\
\text { to attach aeration is performed by four cylindrical } \\
\text { fine bubble membrane diffusers offers good stability } \\
\text { despite variations in organic load and delivers short } \\
\text { start-up time for operation }\end{array}$ & $\begin{array}{l}\text { Eliminates organic } \\
\text { carbon and nitrogen } \\
\text { from municipal } \\
\text { wastewater }\end{array}$ & $\begin{array}{l}\text { (Fdez- } \\
\text { Polanco et } \\
\text { al., 1994) }\end{array}$ \\
\hline
\end{tabular}




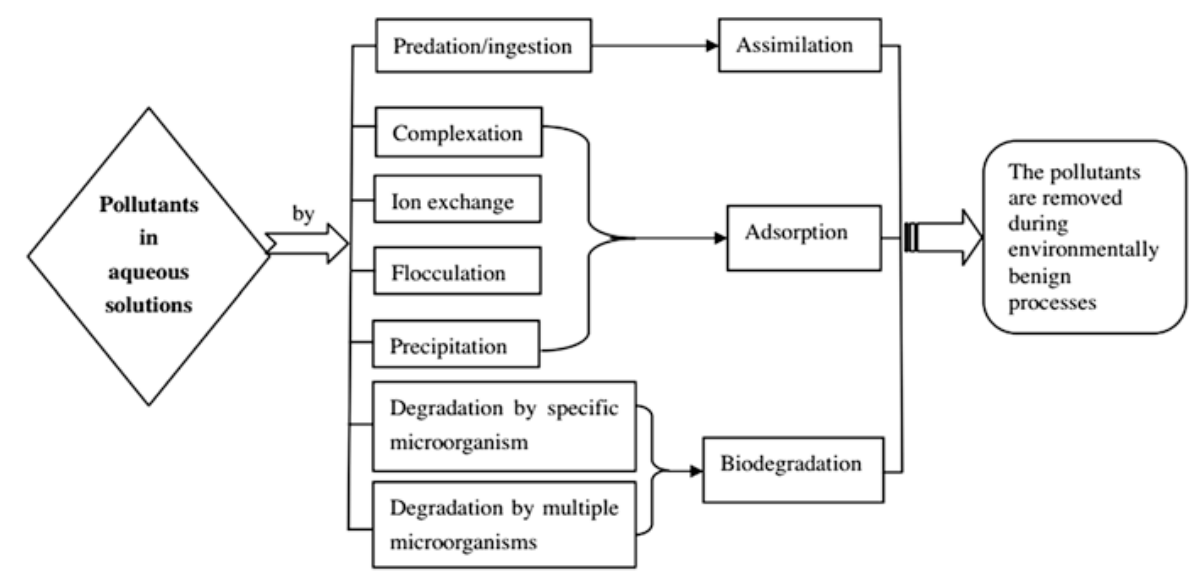

Figure. 2 The method of contaminant removal from aqueous solutions by the conjunct mechanisms of assimilation, adsorption and biodegradation (Wu et al., 2012)

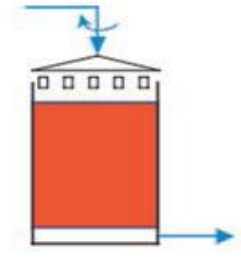

(a)

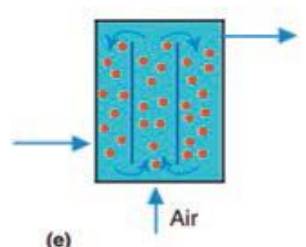

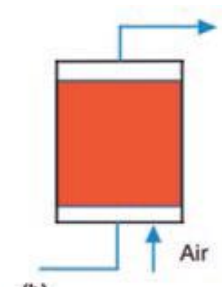

(b)

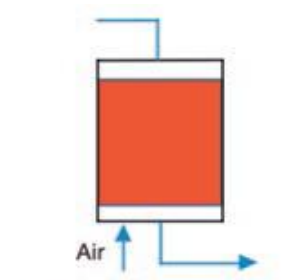

(c)

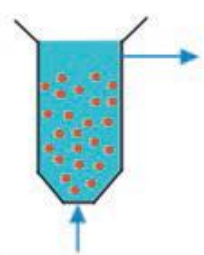

(f)
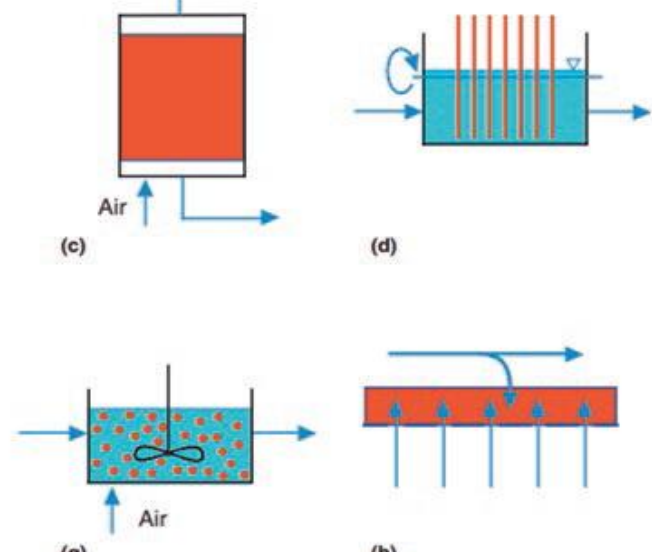

(d)

Figure.3 Types of biofilm reactors: (a) trickling filter; (b) submerged fixed bed biofilm reactor operated as up flow or (c) down flow mode; (d) rotating biological contactor; (e) suspended Biofilm reactor including airlift reactor;

(f) fluidized bed reactor; (g) The moving bed biofilm reactor; and

(h) The membrane attached biofilm reactors. (Morgenroth 2008; Lewandowski et al., 2011)

\section{Disadvantages of biofilm technique}

Some Biofilm based bioreactors are costly.

Needs continuous watch and timely maintenance. However, this drawback can be subsidized by using several physical methods like back washing, mechanical scrubbing etc.

Another problem is biofouling of pipes. Despite of limitations, this technology is suitable and feasible way of combating aquatic pollution.
Control of aquatic pollution requires appropriate infrastructure and management plans. The infrastructure may include wastewater treatment plants, Sewage treatment plants and industrial wastewater treatment plants etc. Agricultural wastewater treatment for farms, and erosion control at construction sites can also help to prevent water pollution. Nature-based solutions are another approach to prevent water pollution. Among all these treatments Biofilm based bioreactors are in use from decades and are 
considered as best available technologies for waste water treatment. Biofilms are complex structured porous and most tolerant communities of the aquatic ecosystem that includes environmentally efficient strains of algae, fungi, bacteria, actinomycetes and viruses. These microbial isolates have been extensively studied for assimilation, biosorption and biodegradation of almost all sorts of organic and inorganic pollutants in aquatic ecosystems. Further research is needed to bio-stimulate the promising strains of biofilms for pollution treatment.

\section{References}

Abou-Zeid, D. M., Muller, R. J., and Deckwer, W. D. (2004): Biodegradation of aliphatic homopolyesters and aliphaticaromatic copolyesters by anaerobic microorganisms. Biomacromolecules, 5, 1687-1697.

Aggarwal, S., Stewart, P., and Hozalski, R. (2016): Biofilm cohesive strength as a basis for Biofilm recalcitrance: Are bacterial biofilms overdesigned. Sage Journals, 8(2), 29-32.

Andersson, S. (2009): Characterization of bacterial biofilms for wastewater treatment. Royal Institute of Technology Stockholm, 1-77.

Battin, T. J., Sloan, W. T., Kjelleberg, S., Daims, H., Head, I. M., and Curtis, T. P. (2007). Microbial landscapes: New paths to biofilm research. Nature Reviews. Microbiology, 5, 76-81.

Battin, T. J., L. A. Kaplan, S. Findlay, C. S. Hopkinson, E. Marti, A. I. Packman, J. D. Newbold, and F. Sabater (2008): Biophysical controls on organic carbon fluxes in fluvial networks. Nature Geoscience 1:95-100. DOI: doi:10.1038/ngeo101

Bestawy, E., AL-Hejin, A., Amer, R., and Kashmeri, R. A. (2014): Decontamination of domestic Biophysical controls on organic carbon fluxes in fluvial networks. Nature
Geoscience, 1, Bioremediation and Biodegradation, 5, 231. Biotechnology Progress, 22, 1256-1264.

Boivin, M. E. Y., Massieux, B., Breure, A. M., Greve, G. D., Rutgers, M., and Admiraal, W. (2006): Functional recovery of biofilm bacterial communities after copper exposure. Environ Pollut. 2006 Mar;140(2):23946. Epub 2005 Nov 3.

Branda, S. S., Vik, F. L., and Kolter, R. (2005). Biofilms: The matrix revisited. Trends in Microbiology, 13(1), 20-26.

China says water pollution so severe that cities could lack safe supplies(2005): Chinadaily.com.cn. June 7.

Cogan, N. G., and Keener, J. P. (2004): The role of the biofilm matrix in structural development. communities to assess short-term structural effects of metals $(\mathrm{Cd}, \mathrm{Zn})$ in rivers. Water Research, 36, 3654-3664.

Cydzik-Kwiatkowska， A. (2015): Bacterial structure of aerobic granules is determined by aeration mode and nitrogen load in the reactor cycle. Bioresource Technology, 181, 312-320.

Daniel, L., Hera, V., and Roberto, K. (2010): Biofilms. Cold Spring Harbor Perspectives in Biology, 2(7), 19430264.

Dasgupta, D., Ghosh, R., and Sengupta, T. K. (2013): Biofilm-mediated enhanced crude oil degradation by newly isolated pseudomonas species. Hindawi Publishing Corporation ISRN Biotechnology, 250749, 1-13.

DeForest, J. L., Drerup, S. A., and Vis, M. L. (2016): Using fatty acids to fingerprint biofilm communities: A means to quickly and accurately assess stream quality. Environmental Monitoring and Assessment, 188, 277.

Del Pozo, R., and Diez, V., (2003): "Organic matter removal in combined anaerobicaerobic fixed-film bioreactors," Water Res., 37, pp. 3561-3568.

Denkhaus, E., Meisen, S., Telgheder, U., and Wingender, J. (2007): Chemical and 
physical methods for characterization of biofilms. Microchimica Acta, 158(1), 127.

Description and Performance of Storm Water Best Management Practices". Preliminary Data Summary of Urban Storm Water Best Management Practices (Report). Washington, DC: United States Environmental Protection Agency (EPA). August (1999): EPA821-R-99-012.

Dhaouadi, H., and Marrot, B., (2008): "Olive mill wastewater treatment in a membrane bioreactor: process feasibility and performances," Chem. Eng. J., 145, pp. 225-231.

Fdez-Polanco, F., Real, F.J., and Garcia, P.A., (1994): "Behaviour of an anaerobic/aerobic pilot-scale fluidizedbed for the simultaneous removal of carbon and nitrogen," Water Sci. Technol., 29, pp. 339-346.

Fu, F., and Wang, Q. (2011): Removal of heavy metal ions from wastewaters: A review. Journal of Environmental Management, 92, 407-418.

Gold, C., Feurtet-Mazel, A., Coste, M., and Boudou, A. (2002): Field transfer of periphytic diatom from industrial effluents-identification and degradation potential. Process Biochemistry, 39,

Hall-Stoodley, L., Costerton, J. W., and Stoodley, P. (2004): Bacterial biofilms: From the natural environment to infectious diseases. Nature Reviews Microbiology, 2(2), 95-108.

Hoellein, T. J., Tank, J. L., Kelly, J. J., and Rosi-Marshall, E. J. (2010): Seasonal variation in nutrient limitation of microbial biofilms colonizing organic and inorganic substrata in streams. Hydrobiologia, 649, 331-345.

Jackson, E. F., and Jackson, C. R. (2008): Viruses in wetland ecosystems. Freshwater Biology, 53,

Jiang, X., Ma, M., and Li, J. (2008): Bacterial diversity of active sludge in waste-water treatment immobilization of Pseudomonas stutzeri using poly propylene granules. International Journal

Johnson, L. T., Tank, J. L., and Dodds, W. K. (2009): The influence of land use on stream Biofilm nutrient limitation across eight North American ecoregions. Canadian Journal of Fisheries and Aquatic Sciences, 66, 1081-1094.

Joo, J. H., Hassan, S. H. A., and Oh, S. E. (2010): Comparative study of biosorption of $\mathrm{Zn} 2+$ by Pseudomonas aeruginosa and Bacillus cereus. International Biodeterioration and Biodegradation, 64, 734-741.

Kahn, Joseph; Yardley, Jim (August 26, 2007): "As China Roars, Pollution Reaches Deadly Extremes". New York Times.

Kao, W. C., Chiu, Y. P., Chang, C. C., and Chang, J. S. (2006): Localization effect on the metal biosorption capability of recombinant mammalian and fish metallothioneins in Escherichia coli.

Kelland, Kate (October 19, 2017): "Study links pollution to millions of deaths worldwide". Reuters. "An overview of diarrhea, symptoms, diagnosis and the costs of morbidity" (PDF). CHNRI. 2010. Archived from the original (PDF) on May 12, 2013.

Kelley and Firestein's Textbook of Rheumatology,Tenth Edition., 2017): Vol-2, pg. 1876-1890

Kong, Y., Xia, Y., Nielsen, J. L., and Nielsen, P. H. (2007): Structure and function of the microbial community in a full-scale enhanced biological phosphorus removal plant. Microbiology, 153(12), 4061-4073.

Kropfl, K., Vlada, P., Szabo, K., Acs, E., Borsodi, A. K., Szikora, S., Caroli, S., and Zaray, G. (2006): Chemical and biological characterization of biofilms formed on different substrata in Tisza river (Hungary). Environmental Pollution, 144, 626-631.

Kwiatkowska, A. C., and Zielinska, M. (2016): Bacterial communities in full-scale wastewater treatment systems. World Journal of Microbiology and 
Biotechnology, 32, 66.

Lear, G., Boothroyd, I. K. G., Turner, S. J., Roberts, K., and Lewis, G. D. (2009): A comparison of bacteria and benthic invertebrates as indicators of ecological health in streams. Freshwater Biology, $54,1532-1543$.

Leguay, S., Lavoie, I., Levy, J. I., and Fortin, C. (2016): Using biofilms for monitoring metal contamination in lotic ecosystems: The protective effects of hardness and $\mathrm{pH}$ on metal bioaccumulation. Environmental Toxicology and Chemistry, 35(6), 14891501.

Lewandowski, Z., Bozeman, M. T., and Boltz, J. P. (2011): Biofilms in water and wastewater treatment (pp. 529-567). Tampa: CH2M Hill Inc.

Ma, Q., Qu, Y., Shen, W., Zhang, Z., Wang, J., Liu, Z., Li, D., Li, H., and Zhou, J. (2015): Bacterial community compositions of coking wastewater treatment plants in steel industry revealed by Illumina high-throughput sequencing. Bioresource Technology, 179, 436-443.

Mages, M., Ovari, M., VonTumpling, W., and Kropfl, K. (2004): Biofilms as bioindicator for polluted waters: Total reflection X-ray fluorescence analysis of biofilms of the Tisza river (Hungary). Analytical and Bioanalytical Chemistry, 378, 1095-1101

Mangwani, N., Shukla, S. K., Rao, T. S., and Das, S. (2013): Calcium-mediated modulation of Pseudomonas mendocina NR802 biofilm influences the phenanthrene degradation. Colloids and Surfaces, B: Biointerfaces, 114, 301309.

Morgenroth, E. (2008): Modelling biofilm systems. In M. Henze, M. C. M. van Loosdrecht, G. Ekama, and D. Brdjanovic (Eds.), Biological wastewater treatment - Principles, modelling, and design (pp. 457-492). London: IWA Publishing. Mathematical Medicine and Biology, 21(2), 147-166.
Moss, Brian (2008): "Water Pollution by Agriculture" (PDF). Phil. Trans. R. Soc. Lond. $\quad$ B. $\quad 363:$ 659-666. doi:10.1098/rstb.2007.2176. PMC 2610176. PMID 17666391

Nguyen, H. T., Le, V. Q., Hansen, A. A., Nielsen, J. L., and Nielsen, P. H. (2011): High diversity and abundance of putative polyphosphate-accumulating Tetrasphaera related bacteria in activated sludge systems. FEMS Microbiology Ecology, 76(2), 256-267.

Nielsen, P. H., Mielczarek, A. T., Kragelund, C., Nielsen, J. L., Saunders, A. M., Kong, Y., Hansen, A. A., and Vollertsen, J. (2010): A conceptual ecosystem model of microbial communities in enhanced biological phosphorus removal plants. Water Research, 44(17), 5070-5088.

Nocker, A., Lepo, J. E., Martin, L. L., and Snyder, R. A. (2007): Response of estuarine Biofilm microbial community development to changes in dissolved oxygen and nutrient concentrations. Microbial Ecology, 54(3), 532-542.

O'Brien, P. J., and Wehr, J. D. (2010): Periphyton biomass and ecological stoichiometry in treams of Biotechnology Applications, 3, 106109.

O’Toole, G., Kaplan, H.B., and Kolter, R., (2000): "Biofilm formation as microbial development," Annu. Rev. Microbiol., 54, pp. 49-79.

Oehmen, A., Lemos, P. C., Carvalho, G., Yuan, Z., Keller, J., Blackall, L. L., and Reis, M. A. (2007): Advances in enhanced biological phosphorus removal: From micro to macro scale. Water Research, 41(11), 2271-2300.

Park, H., Murthy, S., and Bott, C. (2014): Nationwidemetagenome survey of anammox processes via high-throughput next generation sequencing (NGS): 2012-2013. Proceedings of the Water Environment Federation, 2014, 23662371.

Pink, Daniel H. (April 19, 2006): "Investing in 
Tomorrow's Liquid Gold". Yahoo. Archived from the original on April 23, 2006. plant. Earth Science Frontiers, $15,163-168$.

Porsbring, T., Arrhenius, S., Backhaus, T., Kuylenstierna, M., Scholze, M., and Blanck, H. (2007): The SWIFT periphyton test for high-capacity assessments of toxicant effects on microalgal community development. Journal of Experimental Marine Biology and Ecology, 349(2), 299-312.

Qu, X., Ren, Z., Zhang, H., Zhang, M., Zhang, Y., Liu, X., and Peng, W. (2017): Influences of anthropogenic land use on microbial community structure and functional potentials of stream benthic biofilms. Scientific Reports, 7, 15117.

Rakaiby, M. E., Essam, T., and Hashem, A. (2012): Isolation and characterization of relevant algal and bacterial strains from Egyptian environment for potential use in photosynthetically aerated wastewater treatment. Journal of Bioremediation and Biodegradation, S8(001), 1-5.

Reisinger, A. J., Tank, J. L., and Dee, M. M. (2016): Regional and seasonal variation in nutrient limitation of river biofilms. Freshwater Science, 35(2), 474-489.

Ren, Z., Jiang, Z. Y., and Cai, Q. H. (2013): Longitudinal patterns of periphyton biomass in Qinghai- Tibetan Plateau streams: An indicator of pasture degradation. Quaternary International, $313,92-99$.

Rozitis, D. Z., and Strade, E. (2014): COD reduction ability of microorganisms isolated from highly loaded pharmaceutical wastewater pretreatment process. Journal of Mater Environmental Sciences, 6(2), 507-512.

Ryder, D. S., and Miller, W. (2005). Setting goals and measuring success: Linking patterns and processes in stream restoration. Hydrobiology, 552, $147-$ 158.

Sabater, S., Guasch, H., Ricart, M., Romani, A., Vidal, G., Klunder, C., and Schmitt-
Jansen, M. (2007): Monitoring the effect of chemicals on biological communities. The biofilm as an interface. Analytical and Bioanalytical Chemistry, 387(4), 1425-1434.

Sekar, R., Nair, K. V. K., Rao, V. N. R., and Venugopalan, V. P. (2002): Nutrient dynamics and successional changes in a lentic freshwater biofilm. Freshwater Biology, 47, 1893-1907.

Sheng, G. P., Yu, H. Q., and Li, X. Y. (2010): Extracellular polymeric substances (EPS) of microbial aggregates in biological wastewater treatment systems: A review. Biotechnology Advances, 28, 882-894.

Singh, P., and Cameotra, S. S. (2004): Enhancement of metal bioremediation by use of microbial surfactants. Biochemical and Biophysical Research Communications, 319, 291-297.

Singh, R., Paul, B., and Jain, R. K., 2006: "Biofilms: implications in bioremediation," Trends Microbiol., 14, pp. 389-397.

Sivasamy, A., and Sundarabal, N. (2011): Biosorption of an azo-dye by Aspergillusniger and Trichoderma sp. fungal biomasses. Current Microbiology, 62, 351-357.

Smucker, N. J., Detenbeck, N. E., and Morrison, A. C. (2013): Diatom responses to watershed development and potential moderating effects of near-stream forest and wetland cover. Freshwater Science, 32, 230-249.

SriuNaik, S., Y. PydiSetty, Biological denitrification of wastewater in aFBBRd by immobilization of Pseudomonas stutzeri using poly propylene granules,(2011): Int. J. Biotechnol. Appl., 3., 106-109.

Srivastava, J. K., Chandra, H., Kalra, S. J. S., Mishra, P., Khan, H., and Yadav, P. (2017): Plant- microbe interaction in aquatic system and their role in the management of water quality: A review. Applied Water Science, 7, 1079-1090.

Stoodley, P., Sauer, K., Davies, D. G., and 
Costerton, J. W. (2002): Biofilms as complex differentiated communities. Annual Review of Microbiology, 56, 187-209.

Tartakovsky, B., Manuel, M.F., and Guiot, S.R., (2005): "Degradation of trichloroethylene in a coupled anaerobic-aerobic bioreactor: modelling and experiment," Biochem. Eng. J., 26, pp. 72-81.

Tatarko, M., and Bumpus, J. A. (1998): Biodegradation of Congo Red by Phanerochaete chrysosporium. Water Research, 32, 1713-1717.

Teittinen, A., Taka, M., Ruth, O., and Soininen, J. (2015): Variation in stream diatom communities in relation to water quality and catchment variables in a boreal, urbanized region. Science of the Total Environment, 530, 279-289.

Villaverde, S. (2004): Recent development on biological nutrient removal processes for wastewater treatment. Reviews in Environmental Science and Biotechnology, 3, 171-183.

von Sperling, M., and de Lemos Chernicharo, C.A., (2005): "Biological wastewater treatment in climate regions," London: IWA Publishing.

Wang, Y., Tian, Y., Han, B., Zhao, H. B., Bi, J. N., and Bl, C. (2007): Biodegradation of phenol by free and immobilized Acinetobacter sp. strain PD12. Journal of Environmental Sciences, 19, 222225.

Wang, Z., Zhang, X. X., Lu, X., Liu, B., Li, Y., Long, C., and Li, A. (2014): Abundance and diversity of bacterial nitrifiers and denitrifiers and their functional genes in tannery wastewater treatment plants revealed by high-throughput sequencing. PLoS One, 9(11), 113-603.

Watnick, P., and Kolter, R. (2000): Biofilm, city of microbes. Journal of Bacteriology, 182(10), 2675-2679.

Watnick, P., and Kolter, R., (2000): "Biofilm, city of microbes," J. Bacteriol., 182, pp. 2675-2679.

West, Larry (March 26, 2006): "World Water Day: A Billion People Worldwide Lack Safe Drinking Water". About.com. within an urban to rural land-use gradient. Hydrobiologia, 657, 89-105.

$\mathrm{Wu}, \mathrm{Y} ., \mathrm{He}, \mathrm{J}$. , and Yang, L. (2010): Evaluating adsorption and biodegradation mechanisms during the removal of microcystin-RR by periphyton. Environmental Science and Technology, 44, 6319-6324.

Wu, Y., Li, T., and Yang, L. (2012): Mechanisms of removing pollutants from aqueous solutions by microorganisms and their aggregates: A review. Bioresource Technology, 107, $10-18$.

Xuemei, W., Jingling, L., Muyuan, M., and Zhifeng, Y. (2010): Response of freshwater biofilm to pollution and ecosystem in Baiyangdian Lake of China. Procedia Environmental Sciences, 2, 1759-1769.

\section{How to cite this article:}

Rashmi Prabha Mishra, Chandra Kanta Mishra, Navin Kumar and Sudhir Kumar Das. 2020. Combatment of Aquatic Pollution through Biofilm Technique: A Review. Int.J.Curr.Microbiol.App.Sci. 9(04): 1421-1433. doi: https://doi.org/10.20546/ijcmas.2020.904.169 